\title{
Abuso e repressão: fibras do mesmo fio na infância das meninas de Helena Parente Cunha
}

\author{
Lílian Almeida de Oliveira Lima ${ }^{1}$
}

Eu tenho a minha infância e um eco surdo de tambores no escuro.

Myriam Fraga

A produção ficcional da escritora brasileira Helena Parente Cunha é marcada pela presença de personagens femininas e pela problematização desse universo, abalando estruturas e padrões hegemônicos. Avultam em suas tramas personagens jovens e maduras; todavia, as meninas também tomam lugar na denúncia de dores e opressões impostas por moldes culturalmente estabelecidos. Os enquadramentos de gênero ocorrem desde a mais tenra idade. É na infância que eles são disseminados fortemente com vistas à "formação" das crianças, emoldurando-as às convenções culturais acerca do que é feminino e do que é masculino.

No século XVIII, com o surgimento da filosofia das Luzes, como pontua Maria Lúcia Rocha-Coutinho (1994), e da noção de infância, uma revolução sentimental ocorre a partir das ideias de igualdade e felicidade, proporcionando o desenvolvimento da amorosidade. Como assinala Philippe Ariès, "a família tornou-se o lugar de uma afeição necessária entre os cônjuges e entre pais e filhos, algo que ela não era antes. Essa afeição se exprimiu, sobretudo, através da importância que se passou a atribuir à educação" (Ariès, 1981, p. 11). A criança passa a assumir uma posição diferente no contexto familiar; ela adquire valor e importância, e os adultos passam a se ocupar com a sua instrução:

Os adultos passam a se preocupar com sua (das crianças) educação, carreira e futuro. Tornou-se conveniente manter as crianças em casa durante o máximo de tempo possível e "amarrá-las psicológica, financeira e emocionalmente à unidade familiar até o tempo em que estivessem prontas para criar uma nova unidade familiar". Foi criada, assim, a Era da Infância (Rocha-Coutinho, 1994, p. 29).

\footnotetext{
${ }^{1}$ Doutora em teoria da literatura e professora da Universidade do Estado da Bahia (UNEB), Salvador, BA, Brasil. E-mail: lirioalmeida@yahoo.com.br
} 
Por conta do reconhecimento de que a criança não é um adulto em miniatura, ela torna-se alvo das atenções adultas, que visam a educá-la, moldá-la segundo os padrões socioculturalmente aceitos. Ao se dispor a "formá-la", os adultos estabelecem as bases de crescimento e desenvolvimento dos pequenos seres que, mais tarde, serão adultos também, confirmando a concepção de criança comumente aceita e exposta por Manuel Jacinto Sarmento: “a criança é considerada como não adulto, e este olhar adultocêntrico sobre a infância registra especialmente a ausência, a incompletude ou a negação das características de um ser humano 'completo'" (Sarmento, 2007, p. 33). A proposta de formação costuma vir sobrecarregada de formatos e modelos que a criança deve aprender e aos quais deve se adequar. É nesse momento que os enquadramentos de gênero são disseminados e que as vozes castradoras se impregnam na menina, contribuindo sobremaneira para a manutenção dos paradigmas hegemônicos a que outras personagens femininas, adultas, se veem enredadas.

A meninice não é só o momento de aprendizagem de conhecimentos e comportamentos distintos, de formação. É também um momento de grande vulnerabilidade. Ingênuas, as meninas costumam ser alvo de descuidos e psicopatias, sobretudo quando se aproximam da puberdade ou já estão na adolescência. Nessa fase, costumam ser bastante fortes as delimitações e programações estabelecidas pela família, gerando inculcações que as mantêm presas ao temor de contrariar as formatações definidas. Presas ou não aos limites e ensinamentos familiares, as meninas parenteanas desfiam o abuso e a opressão como fibras do mesmo fio de violação a que são submetidas fora ou dentro de casa. Elas vivenciam a dor, a culpa, a vergonha, a resignação, contrariando a noção de que a infância é a fase da vida de plenitude e felicidade sem igual.

No conto "A dívida", do livro Os provisórios (1990b), o que se tem é o sentimento de vergonha, que parece ser reforçado pela linguagem acelerada, desprovida de vírgulas, resultante de uma dívida de dois anos. A infância da personagem é alijada das descobertas e alegrias da meninice em decorrência do abuso insinuado por um adulto, seu Antônio. Na companhia de uma amiga que desejava comer uma cocada da confeitaria de seu Antônio, a protagonista se vê convencida a lhe pedir para vender o doce e pagar depois. O doce é vendido, todavia o pagamento não era exatamente a quantia em dinheiro que representasse o valor da guloseima: 
seu Antônio por favor será que o senhor poderia fazer um favor para nós para mim sim senhor seu Antônio muito obrigada amanhã quando nós sairmos da escola sem falta nós pagamos eu pago está bem seu Antônio o senhor vai nos vender fiado sim a mim obrigada está bem mas só se eu me sentar no seu colo e lhe der um beijo? Amanhã sem falta (Cunha, 1990b, p. 38).

A personagem não volta para pagar a dívida e se vê consumida pela vergonha e medo daquele homem durante dois anos. A transferência do pai para outra cidade era a possibilidade de se livrar do pânico e da sujeição aos desejos de seu Antônio. Dois anos da infância dessa menina são aterrorizados pelo peso da dívida, sobretudo, ainda que subrepticiamente, pelo constrangimento do ato abusivo deflagrado pelo comerciante, o que a levou a não voltar para pagar o valor da cocada em dinheiro nem para atender à proposta. A cabeça infantil teme a cobrança da dívida, do valor do produto consumido, teme a exposição da situação ao pai. As perguntas "por que não voltou lá para pagar?" e "como explicar tal situação?" envolvem-na em uma teia de horror ante a possibilidade de encontrar, a qualquer momento e em qualquer lugar, o dono da confeitaria, como se vê a seguir:

Envergonhada foi adiando o pagamento encabulada sem coragem de enfrentar o homem sempre deixando para o dia seguinte até compreender que não teria mais cara para voltar lá [...] o pior se tornara o medo de encontrar o homem nas ruas ou na praça ou na igreja pois ela o via em todos os lugares atrás dela sempre por mais que se escondesse e fugisse (Cunha, 1990b, p. 37).

O medo paralisa-lhe a infância. O que mobiliza o temor é menos a cobrança moral em relação ao valor monetário não pago do que a aversão à invasão e violação perpetradas pelo ato mesmo de propor o aliciamento, a prática pedófila. A menina, no entanto, em sua ingenuidade de criança e pudor moral, não percebe o avesso da teia em que se enreda: possivelmente, seu Antônio temia que a situação viesse à tona, revelando seus desejos pedófilos, sua mente doentia. Nesse caso, o descontentamento com a falta moral dela seria minimizado pela proposta libidinosa do comerciante. $\mathrm{O}$ alívio somente ia acontecer com a mudança de cidade.

Semelhante situação de abuso sugestionado é vista no conto "Os botões", do livro Cem mentiras de verdade (1990a). A conversa entre duas meninas revela os desejos também pedófilos de seu Anselmo: 
Por que você não gosta de seu Anselmo? Seu Anselmo gosta de se aproximar dela, olhar ardente, sôfregas mãos. Por que você não gosta de seu Anselmo? Seu Anselmo, sôfregas mãos, gosta de apalpar os peitinhos dela. Outro dia quis meter a mãozona por debaixo da blusa. E o que foi que você fez? Ela saiu correndo, bichinho assustado, passarinho arfante (Cunha, 1990a, p. 6).

Em ambos os contos, a meninice é violada pelas propostas de abuso sugestionado. O momento de transição para a vida adulta, a adolescência, é alvo de interesse doentio de ambas as personagens masculinas, seu Antônio e seu Anselmo. $\mathrm{O}$ disparatado desejo masculino viola a inocência e a ingenuidade das garotas, ao mesmo tempo em que, lido atravessadamente, impele outra personagem, cujos seios ainda não nasceram, a experienciar o despertar do corpo e da sexualidade por uma via adoecida: "A outra menina ouviu no encoberto. Enigma, a vida. Desabotoou o último botão da blusa e foi procurar seu Anselmo. Seus dois botões que ainda vão abrir" (Cunha, 1990a, p. 6).

Destaco a imagem do botão, que intitula o conto, recorrente na narrativa e sinalizadora do lugar etário em que as meninas se encontram. $\mathrm{O}$ botão, enquanto algo que ainda viria a se desenvolver por completo, evoca inicialmente a adolescência, fase da vida que antecede a ampliação da abertura para a vida proporcionada pela fase adulta: "As duas menininhas, dois botões que ainda vão abrir" (Cunha, 1990a, p. 6). Ao final, tem-se o botão significando não só item de costura, usado para fechar roupas, "Desabotoou o último botão da blusa..." (Cunha, 1990a, p. 6), mas também "a flor antes de desabrochar", segundo acepção indicativa do sentido figurado para o verbete "botão" no Dicionário Aurélio da língua portuguesa (Ferreira, Ferreira e Anjos, 2010, p. 6): "Seus dois botões que ainda vão abrir". Estes são os seios a nascer, mais um indicativo da adolescência e da descoberta precoce da sexualidade. E o revelar da sexualidade desperta o desejo ardente das mentes adoecidas das personagens masculinas, ao passo que coloca as personagens meninas em vulnerabilidade física e emocional.

Se, nesse conto, o desejo sexual é externado pela violação do corpo vestido mediante apalpamento, em "Terceira estória do Coronel Titino Cravo", o desejo ultrapassa a inocência ainda infantil, desatando-se na consumação do ato sexual. Investido de seu poder de coronel, Titino Cravo representa a opressão e a dubiedade de valores. Sua filha não pode ser a namorada de seu afilhado, no entanto, a filha de um de seus 
trabalhadores pode ser violada pela sede do coronel. Implicados aí estão a tentativa de preservar a honra da filha e a reafirmação do pátrio poder, ao surrar o jovem e mandá-lo para casa: "agora mesmo, pode voltar pra cidade. E pode dizer a seu pai, meu compadre governador. Minha regra, meu poder. Nas minhas terras sou eu" (Cunha, 1990a, p. 37-38). É a investidura do poder que parece encantar a filha de seu trabalhador, aliada à ingenuidade e à falta de posses:

O Coronel só parou na casa de um dos seus cabras. A moça filha do cabra já estava na janela. Sorrindozinha. Lenço verde na cabeça, vestido de chita verde. Veio vindo no seu vindo devagar. Coronel mandou. Ela amonta na montaria. O cavalo manga-larga leva o patrão e a mocinha na direção do paiol. Devagar e depressa (Cunha, 1990a, p. 38).

A pobreza parece ser a porta da permissividade para o sequestro da meninice também vivido por essa personagem. Diferente das meninas anteriores, "a filha do cabra" parece contar com a anuência da família para o abuso travestido em alegria de servir ao coronel. Relacionar-se sexualmente com o patrão parece sugerir uma minimização da diferença social em que ela e sua família encontram-se em relação ao empregador. Ela própria esboça o tamanho da opressão e ignorância, "sorrindozinha" para o patrão, para um suposto poder adquirido mediante a procura para a cópula e uso de seu jovem corpo. A medida de proteção e defesa da honra é válida apenas para a filha do coronel; para a filha do empregado, uma medida diferente é utilizada: servir ao patrão.

Entre as histórias de abuso e opressão já apresentadas, a da menina de oito anos que não queria ser modelo está entre as mais brutais, por ter como sujeito promotor alguém que deveria assegurar-lhe cuidado, proteção e saúde: a mãe. Em “A menina quer ser modelo?", do livro Falas e falares, uma violenta rotina é imposta a uma garota desde os cinco anos de idade, porém travestida de preocupação com o futuro dela: "desde os cinco anos eu preparo minha filha para ser modelo, olhe aqui meu bem, do jeito que as coisas estão, temos que cuidar do futuro de nossos filhos, o que você está pensando?, balé, ginástica, dança de salão, dieta controlada, desde os cinco anos, eu não vacilo" (Cunha, 2011, p. 99, grifos nossos).

Oprimida entre os horários dos seus compromissos e o que pode e não pode fazer ou comer, ela dá sinais de incompatibilidade com os desejos maternos; todavia, a mãe se recusa a enxergar. Aquilo que parece ser amor e cuidado transparece como violação das condições da 
infância, como opressão psíquica. O abuso realizado aqui é diferente daquele cometido por coronel Titino Cravo, por seu Anselmo ou por seu Antônio. Enquanto eles intencionavam ou mesmo concretizavam a violação física, aqui a agressão é emocional e psíquica, cujos efeitos recaem sobre o físico da criança:

De quinze em quinze dias levo minha filha à pediatra, ela tem uma febrezinha diariamente no fim da tarde, nada sério, e tem dificuldade para seguir a dieta e manter o peso, eu me preocupo com a agenda dela, terapia duas vezes na semana, desde os cinco anos ela chora muito e acorda de noite com pesadelo, coisas de criança, não é, meu bem? (Cunha, 2011, p. 100).

A situação da personagem remete ao desaparecimento da infância, apontado por Neil Postman (1999). Segundo ele, a incorporação pelas crianças de comportamentos adultos e o acesso a informações antes próprias a eles, e vice-versa, promovem a indistinção entre essas duas fases da vida humana e, portanto, o fim da noção de infância. O que a protagonista experiencia é a submissão a atividades adultas com propósitos válidos para os adultos, como Postman problematiza:

Por que alguém desejaria negar às crianças a liberdade, a informalidade e a alegria das brincadeiras espontâneas? Por que submeter as crianças a rigores de treinamento, concentração, tensão e publicidade na mídia à maneira de profissionais? A resposta é a mesma de antes: os pressupostos tradicionais sobre a singularidade das crianças estão desaparecendo rapidamente. $\mathrm{O}$ que temos aqui é o surgimento da ideia de que não se deve brincar só por brincar, mas brincar com algum propósito externo, como renome, dinheiro, condicionamento físico, ascensão social, orgulho nacional. Para adultos, brincar é coisa séria. À medida que a infância desaparece, desaparece também a concepção infantil de brincar (Postman, 1999, p. 145).

É evidente que, escondido sob o véu da preocupação com o futuro da garota, existe um grande desejo materno de ter uma filha modelo, $\mathrm{o}$ que a torna incapaz de enxergar os indícios de insatisfação da criança em relação à rotina imposta para enquadrá-la nos requisitos das agências e campanhas. Interessam à mãe os êxitos "curriculares" obtidos pela menina, a somatória de experiências profissionais e atributos pessoais que a conduzam gradativamente à vida de modelo, aos quatorze ou quinze anos: 
Você sabe quantos comerciais ela já fez na TV?, até fotos em capa de revista, anúncios de cosméticos infantis, ela sabe posar, você precisa ver como ela caminha, já parece uma modelo, e o olhar? [...] quero que minha filha esteja preparada, eu converso com ela, esclareço, desde os cinco anos venho ensinando, aos poucos ela se acostuma, perde a timidez, para isso eu venho lutando, meu bem, desde os cinco anos, viu?, mas ainda temos tempo, até ela completar quatorze, quinze anos (Cunha, 2011, p. 99, grifos nossos).

É pertinente destacar os vocábulos usados pela mãe para expor seu empreendimento filial. As expressões grifadas em citações anteriores mostram que ela não vacila, mas conversa, esclarece, ensina, vem lutando para transformar a filha numa modelo. As palavras, sobretudo as expressões "não vacilar" e "vir lutando", revelam o esforço materno gerado no intuito de ter seu objetivo realizado, ao mesmo tempo em que evidenciam a intensidade da pressão sobre a menina. A cena narrativa expõe o que Manuel Jacinto Sarmento chama de "privatização da infância":

A "privatização" da infância corresponde a um dispositivo de proteção das crianças, tanto quanto de subordinação a um regime de autoridade paternalista. A imagem da criança com um quotidiano superpreenchido, deslocando-se da família para a escola e daqui para as inúmeras atividades de formação complementar, das aulas de língua estrangeira ao ballet e do clube de informática às atividades desportivas, ilustra bem atividade dependente e vigiada sob controle adulto, numa extensão custodial do poder familiar, agora alargado às múltiplas agências de ocupação infantil (Sarmento, 2007, p. 40).

A mãe, todavia, nega o exercício de opressão, o que pode ser lido como uma grande ironia: "e eu não forço nada, não insisto, só não quero que ela vá ao Mc Donald, com a tendência para engordar, meu bem, Mc Donald proibidíssimo, aí eu não transijo" (Cunha, 2011, p. 100). As orações finais contrariam toda a fala inicial, sobrepujando o caráter autoritário da mãe.

A violência cometida pela mãe compromete a integridade emocional da filha, submetida a uma rotina infantil alterada, alijada da leveza e descontração que deveriam identificar tal etapa da vida. A descaracterização é tamanha que a permissão para brincar com bonecas aos oito anos de idade constitui-se em um gesto de 
benevolência - "por enquanto, eu não me importo que ela brinque com bonecas, afinal as meninas de oito anos ainda gostam, não é, meu bem?" (Cunha, 2011, p. 99) -, uma vez que todo o resto de suas atividades é regido por proibições e controles, lembrando o desaparecimento do brincar postulado por Neil Postman. Diante desse cenário de opressão, ironicamente, é a mãe quem sofre ao receber a notícia de que a filha mais uma vez passou mal: "desmaiou?, a febre é alta?, eu já vou para aí, diga a ela que não chore, chego em dez minutos, você está vendo, ela ficou nervosa, tudo isso é reação, medo de desfilar para representantes das grifes de revistas de moda infantil, ah, meu bem, mãe sofre demais" (Cunha, 2011, p. 100). A obsessão materna a impossibilita de enxergar o sofrimento que explode na criança, de ver toda a dor e opressão que gritam sob a forma de febre, pesadelo e desmaio. A cegueira da mãe só lhe permite enxergar a filha como sujeito de realização do seu desejo.

No conto "Amor de filha", a opressão e a dor são marcas presentes. Não uma opressão oriunda de um sujeito externo, como na estória do coronel Titino Cravo, mas a opressão originária do zelo e amor pela mãe. A menina desdobra-se em cuidados com a mãe com medo de perdê-la durante os partos de seus irmãos, situação ocorrida com uma vizinha, que deixa o marido viúvo, sozinho, depois de parir:

Ela tinha muito medo que a mãe viesse a morrer de parto como dona Vivi, e então ela procurava ajudar a mãe, cheia de cuidados, pressurosa, apanhava a tesoura que havia caído no chão, a mãe pesada, a barriga muito grande, a menina olhava atenta e preocupada, ia muitas vezes buscar água e insistia para a mãe beber, não, não, ela não podia se cansar, todo o zelo se desdobrava em pequenos gestos, se redobrava numa presença obsessiva, como se a menina tivesse o dom da proteção e enquanto ficava cada vez mais apreensiva não conseguia dormir, o seu quarto pegado ao da mãe (Cunha, 1990b, p. 101).

O medo da morte da mãe oprime a garota que se distende, obsessivamente, em cuidados. A relação mãe-filha é completamente invertida no tocante à função de cuidadora e ser cuidada. O papel de filha primogênita atrela a essa menina o dever de cuidar de qualquer que seja o membro da família, sobretudo, cuidar da mãe que lhe transmitiu a vida, figura envolvida numa aura sagrada pelos preceitos cristãos. 
O desmedido zelo reincide na segunda gravidez da mãe, assim como o medo de ver a história de dona Vivi, repetir-se e o desconforto de se manter diligente. $\mathrm{O}$ parto constitui o ápice do medo e da opressão impelida pela dúvida: a mãe estava morta?

Vamos, força, agora, a mãe gemia alto, estaria chorando? Estaria doendo muito? o que estava acontecendo? a menina assustada não dormia, [...] o barulho dos passos apressados, mais água, mais gemidos, [...] mais vozes cochichando, a menina mais sozinha no quarto ao lado, vamos, força, está quase, a menina sem respirar no canto da cama, mais água para quê? a menina encolhida, silêncio, mamãe morreu? cochichos, meu Deus, não deixe que mamãe morra, se ela não morrer eu rezo 9 terços de joelhos, 9 sextas-feiras seguidas e acendo 9 velas no oratório de Nossa Senhora, meu Deus, por favor, não deixe mamãe morrer, silêncio, ela morreu? (Cunha, 1990b, p. 102).

A pergunta desdobra-se na angústia de não saber o que acontecia com a mãe, de apenas ouvir os rumores do trabalho de parto, acuada em seu quarto. $\mathrm{O}$ apelo ao divino revela sua impotência diante da situação, na medida em que também sinaliza a potência de sofrimento da personagem. A aflição da filha é enfatizada pela voz narrativa, através das seguintes construções: "atenta e preocupada" (Cunha, 1990b, p. 101), fica "cada vez mais apreensiva" (p. 101), "não dormia, um cansaço, um pavor" (p. 101), "assustada não dormia” (p. 102), ficava "sem respirar no canto da cama" (p. 102). A tensão é suspensa pelo choro do irmãozinho ou pelo movimento de pessoas comentando a beleza do mais novo membro da família, indícios de que a mãe não morreu. Recuada no canto de algum cômodo, ela olha o rebuliço proveniente do nascimento, solitária, atenta. É válido notar a solidão da menina, várias vezes mencionada, e que contribui para a sensação de aflição. "A menina mais sozinha no quarto ao lado" (p. 102) acompanha, auditivamente, o parto e, também em estado de isolamento, as visitas à puérpera e ao recém-nascido: "a menina se sentia sozinha em meio àquela gente, mais sozinha, viveu a morte da mãe duas vezes, dois irmãos, ela temia a morte da mãe" (p. 103). A situação de tensão e sofrimento da protagonista parece sugerir uma inversão no tocante aos papéis de filha e de mãe. À mãe caberia assegurar o cuidado e o zelo pela vida não apenas dos filhos, mas dela própria; todavia, eles são assumidos pela filha. $\mathrm{O}$ esmaecimento dos lugares de adulto e de 
criança constatados por Neil Postman (1999), mais uma vez, evidenciase, confirmando a dissolução da infância e a alteração das tradicionais ordens e hierarquias familiares.

Em meio a todo esse desgaste emocional da personagem, é importante também assinalar as marcas que remetem à possibilidade de uma leitura psicanalítica para o conto. A morte de dona Vivi e o encadeamento da situação do viúvo, sempre mencionada ao lado das notícias sobre o medo de a mãe morrer de parto, bem como o desfecho com o viúvo casando-se novamente e a constatação de que a mãe não morreu, estabelecem uma ligação entre a morte da mulher, o homem sozinho e a solidão da menina. Embora inexista a presença do pai da garota, pode-se ler, por analogia, o complexo de Édipo e o desejo da filha de ocupar o lugar materno junto ao pai, veementemente exposto em um diálogo estabelecido em um tempo não mais da infância: "ela esperava a morte da mãe para reinar soberana na casa, é mentira, eu sempre amei a minha mãe, você tinha ciúmes dela, queria ficar no lugar dela, é mentira, eu sempre amei minha mãe, eu tinha medo de que ela morresse e me deixasse sozinha" (Cunha, 1990b, p. 103). Adulta, a personagem ratifica: "vivo só para minha mãe. E, naturalmente, para meu pai, que não pode ficar sozinho, quando minha mãe morrer" (p. 103). A declaração evidencia a devoção ao cuidado com a mãe, e com o pai, na morte daquela, confirmando a leitura edipiana do comportamento da personagem, revelada na fase adulta. Todavia o destaque que interessa neste momento diz respeito à infância, e, na meninice, as atitudes regidas pelo complexo de Édipo não estão na superfície do consciente infantil. Antes, o que impera é a tensão emocional do conflito entre temer a morte da mãe, cuidar e protegê-la da morte e se reconhecer impotente diante da tarefa. Tudo isso insere a menina numa órbita, onde gravitam o sofrimento, a opressão interior e a dor, elementos bastante presentes nas infâncias construídas por Helena Parente Cunha para suas personagens.

Girando em torno desses três elementos - sofrimento, opressão e dor , está a personagem de "Orgulho ofendido". Menina pobre em escola de meninas ricas, eis o leitmotiv para desfiá-los. O valor da escola era abonado por uma espécie de bolsa, adquirida através de amizade. Todavia, isso não era o bastante, pois estar ali exigia o pagamento de um preço talvez alto demais para a garota: 
A menina muito pobre, na escola de meninas muito ricas. Por quê? Razão que o pai dela conseguiu. Amigo de um amigo da diretora, não precisa pagar. A roupa limpa, os sapatos engraxados, a pasta ganhou da madrinha. Ela fingia que não pertencia à pobreza. As outras meninas. Umas fingiam que não sabiam. Outras mostravam que mais sabiam (Cunha, 1990a, p. 34).

Algumas colegas omitiam a condição social da menina, enquanto outras expunham a distância que as diferenciava na ostentação das viagens ao exterior ou nos presentes exorbitantes. Recuada na ausência de recursos, a menina se diminuía e sofria com a explicitação das suas carências, com a solidariedade cheia de pena oferecida pelas garotas ricas: Vou passar as férias na Europa e você? Na formatura meu pai vai me dar um carro de presente e o seu? A menina muito pobre tudo ouvia, rebatia no estreitamente. Sorria raso. Ao fundo doía. [...] E a festa de formatura? Ela não ia? A madrinha deu o vestido de baile. E o álbum de formatura? As colegas decidiram. Iam dar o álbum de formatura. Ela sorria raso. Ao fundo doía. Não queria. As meninas insistiam. As meninas que mostravam que sabiam mostravam que tinham pena (Cunha, 1990a, p. 34).

Estar naquele ambiente de garotas muito ricas, cheias de superioridade e discriminação, mantinha a menina pobre em desconfortável enfrentamento das diferenças sociais. Reduzida na escassez financeira, ela apenas se recolhe no sorriso e na dor, tentando assemelhar-se naquilo que era possível, o uniforme e o rendimento escolar: "de noite lavava a blusa da escola, de manhã ela passava. Engraxava seus sapatos. Estudava nos livros das meninas que fingiam que não sabiam. Passou de ano" (Cunha, 1990a, p. 34). A protagonista de "Orgulho ofendido" apresenta um comportamento emaranhado na dor que "ao fundo doía" e na consciência do seu lugar social presentificado nas relações dentro do espaço escolar, evidenciando o que Maria Adelaide Rua constatou mediante um estudo de caso realizado com crianças carentes em bairros pobres da Cidade do Porto (Portugal):

As crianças possuem quer uma enorme capacidade de interpretação simultânea dos diferentes mandatos e sua reelaboração em normas de conduta, atitudes, comportamentos que, tanto quanto possível, lhes permitam sentir integradas, incluídas em todas as instâncias socializadoras, quer uma clara consciência das relações que unem determinadas vivências a 
determinados sentimentos, isto é, conhecem bem como o seu mundo interior se encontra articulado aos mundos exteriores (Rua, 2007, p. 239).

A opressão sempre é sinalizada, apesar da solidariedade de algumas colegas, seja pelas perguntas sobre viagens ou presentes, seja através das "caridades odiosas" 2 promovidas pelo sentimento de pena. É esse sentimento de dó que flagela a menina pobre, uma vez que, vinculado a ele, encontra-se o estigma de coitadinha mantido pelas colegas que "mostravam que mais sabiam". Porém, evidenciar o conhecimento sobre as diferenças que as separavam não era o suficiente, o desejo de mais segregar e rebaixar a colega pobre culmina com a humilhação:

Iam dar o álbum de formatura. [...] As meninas que mostravam que sabiam mostravam que tinham pena. Nem raso ela sorria. E no baile. Esta é a menina. Mais doía. Depois do baile, pegou o álbum de formatura. Em rasgado se rasgou. E os pedaços mais pedaço em se queimou (Cunha, 1990a, p. 34).

O odioso gesto de dar o álbum passava longe da piedade; ele tinha, por trás, mais uma vez, o desejo de discriminar a personagem. É mediante a discriminação e a humilhação que a menina pobre se vê cercada pelo sofrimento, pela opressão e pela dor. O preço que ela paga por frequentar um espaço economicamente diferente daquele que seria comum a sua classe social é bastante elevado: sua integridade moral.

A dor é marca predominante também em "O noivado". Lili, uma garota de cinco anos, acredita nas falas de Miltom, um empregado do pai dela: "Olhe, Lili, você é minha noiva. Quando você crescer vai se casar comigo. Lili muito contente ouve aquele rapagão bonito que veio trabalhar na loja do papai" (Cunha, 1990b, p. 81). A menina acredita e se divide entre as meninices e brincadeiras da infância e a crença nas palavras de Miltom, sempre na expectativa da presença dele, no desejo de lhe corresponder as falas: "Lili brinca com as meninas das casas vizinhas, pula corda, corre picula. Papai, Miltom vem hoje aqui? Miltom ia. Minha noiva, você gosta dessa boneca? Lili gostava. Minha noiva, você já aprendeu as letras? Lili pede ao pai uma cartilha. Minha noiva" (Cunha, 1990b, p. 81). É válido assinalar a aquiescência da menina às falas do rapaz, parecendo querer agradá-lo, que pode ser lida como

\footnotetext{
${ }^{2}$ Expressão que intitula uma crônica de Clarice Lispector presente no livro A descoberta do mundo (1994).
} 
reprodução de um modelo referente à educação feminina, o de que a esposa deve satisfazer o marido. Estando Lili noiva dele, portanto a um passo de assumir o papel de esposa, era prudente exercitar o que, mais tarde, exerceria, tornando-se esposa. Os gestos da menina dão o indício de uma educação voltada para os tradicionais papéis masculinos e femininos. Como salienta Maria Lúcia Rocha-Coutinho, as formatações necessárias para reproduzir os modelos solicitados na adultidade têm início quando se é criança:

Os tipos de comportamento encorajados nas meninas supostamente as preparavam para desempenhar os seus futuros papéis no lar e na família. Acima de tudo, elas eram educadas no sentido de se orientarem para relacionamentos, isto é, eram orientadas para os outros e não para si mesmas (Rocha-Coutinho, 1994, p. 58-59).

O rapaz conquista a menina com brincadeiras e passeios, a confiança está ganha quando o pai resolve mudar de cidade, interrompendo a relação estabelecida entre os dois e promovendo a tristeza da filha: "Lili, venha se despedir do Miltom. Lili!! Cadê Lili? Ninguém achou Lili escondida atrás da porta" (Cunha, 1990b, p. 82). Porém, o afastamento não impede a garota de continuar nutrindo a crença de que é a noiva de Miltom. Na festa de dez anos, ela se veste vaidosamente, diverte-se e adia o quanto pode os parabéns, esperançosa pelo reencontro com Miltom:

Lili venha soprar as suas velas. Daqui a pouco. Lili ia muitas vezes à janela. Lili vai algumas vezes ao jardim. Lili ouve o bonde parando pertinho. Ela faz de conta que não presta atenção. Lili não quer acender as velas agora. Mais tarde. Papai, você não disse que o Miltom hoje vinha aqui? Você se lembra do Miltom, Lili? Lili não se esqueceu. Que horas o Miltom disse que vinha, papai? Papai, você disse a ele que era meu aniversário? [...] Lili, venha acender as velas, já está muito tarde. Miltom! Até que enfim você chegou (Cunha, 1990b, p. 82).

A expectativa gerada pelo desejo do encontro com Miltom é responsável pela frustração que virá em seguida. Ele chega acompanhado pela noiva, gerando, na menina, o sentimento de decepção decorrente da "traição". Inocentes, as crianças costumam acreditar no que lhes é dito, sem dispor de condições para avaliar o grau de veracidade das informações; elas simplesmente acreditam. Lili acreditou e confiou nas palavras de Miltom, não o esqueceu e aguardou, até o último momento, para celebrar o seu aniversário na presença dele. 
Todo um investimento emocional foi engendrado pelo rapaz, mantido pela garota desde os cinco aos dez anos de idade, o suposto noivado, e interrompido pela presença da futura esposa dele: "Miltom segura a mãozinha gelada de Lili. Lili foi minha primeira noiva. Você se lembra? Você era deste tamanhozinho sentada no meu colo, parecia que entendia de verdade eu dizer que você era minha noiva. Lili você vai ficar uma moça linda, me dê um beijo" (Cunha, 1990b, p. 83).

Ele, em seu ponto de vista de adulto e sua incompreensão quanto às emoções e cognições infantis, não percebia que Lili não apenas entendia o que era dito, mas acreditava na ideia de ser noiva dele. Estabelecida a quebra da confiança, restou à menina desaparecer com sua dor da festa de aniversário. Para Miltom ficavam as lembranças de suas falas despretensiosas para Lili. Sua chegada à festa com a noiva não promoveu nele qualquer fissura emocional. Tudo o que foi dito na infância de Lili não passava de brincadeira, para ele, e dessa brincadeira sobrou o sentimento ferido da menina, resultante do desencontro entre as perspectivas infantil e adulta.

No conto "Vergonha", a infância da protagonista é marcada pela vergonha e pela culpa, oriundas de situação que ela desconhece: a mãe é uma prostituta. Criada pelos tios, ela acumula a vergonha diante de sua história não contada: quem era o seu pai? Quem era a sua mãe? O constrangimento vinha mediante as colegas da escola e suas perguntas cheias de risos. Recolhendo de conversas os fragmentos dos motivos da culpa, ela compreende que houve uma desonra que levou o avô à morte. Ela própria era a vivificação da desonra e o motivo da morte do avô: "pouco a pouco entendendo que a vergonha que ela sentia não era bem dela mas era ela a vergonha registrada na família honrada onde nunca houvera nada semelhante e então entendeu sua culpa - o avô morreu por sua causa - não suportou a vergonha" (Cunha, 1990b, p. 14) . Mais uma vez, a ausência de pontuação abreviando qualquer pausa, qualquer delonga na exposição dos fatos, na exibição da própria vergonha, parece ratificar o sentimento de humilhação e a vontade de encurtar o momento de desnudamento. $O$ desejo de se apagar, redimindo-se da culpa que sentia, era pungente, levando-a a uma condição de resignação. Uma infância apagada pela condição de abrigada, envergonhada e culpada assegurava-lhe a condição de servilismo perante os tios, poupando-os de maiores descontentamentos: 
Logo aprendeu que morar era um favor aprendeu que dizer muito obrigada era ficar mesmo obrigada [...] quanto mais ela entendia mais obedecia mais procurava compensar a família honrada pelo favor de lhe dar casa e comida e cada vez mais entendia que não devia chorar e não chorava sempre mais calava atrás das lágrimas que não rolavam (Cunha, 1990b, p. 14).

A partir da resignação e da obrigação de destituir-se de si, nota-se a repressão do desejo de expor as dores e os desconfortos, ocultando-os. Marilena Chaui, em Repressão sexual: essa nossa (des)conhecida, discutindo as acepções para o verbo reprimir, esclarece: "reprimir é assegurar ou interromper um movimento ou uma ação e que isso é feito seja pela punição e pelo castigo, seja pela proibição e pela ameaça, seja pelo sentimento do desagrado que leva a dar sumiço em alguma ideia, afeto ou ação, ocultando-os" (Chaui, s.d., p. 16). O castigo ou punição imputada sobre a personagem é a vergonha, cuja personificação é ela própria. Em nome da vergonha, a menina se reprime em atendimento às vontades e expectativas alheias, especialmente as de sua mãe.

A mãe a visitava, com o intuito de conferir se já era hora de tirá-la da casa dos tios. Verificava o crescimento dos seios, a cintura, as nádegas, o ventre, até o dia em que ela já estaria pronta para ir morar onde a mãe morava. O novo quarto era o alívio para o sofrimento de ter de omitir os seus desconfortos: "a menina foi morar num quarto que era dela mesma e onde afinal ela podia vomitar livremente na pia sem se preocupar em esconder dos outros que estava vomitando" (Cunha, 1990b, p. 15). A liberdade para vomitar diante do cheiro do perfume da mãe, metonímia das repressões a que a garota se submete, representa a descompressão da protagonista que, somada à sua ingenuidade, obscurecem a invasora e violenta realidade em que ela terá de se enquadrar. A saída da casa dos tios não significará a liberdade e a leveza que costumam ou deveriam envolver a meninice e a infância. No conto em questão, a mãe, figura que costuma estar associada ao cuidado e bem estar infanto-juvenil, despe-se completamente dessa função, garantindo a manutenção do seu negócio: a prostituição. Não há pudor, vergonha, nem traços de qualquer repressão, impressos no comportamento materno. A vergonha que sequestra a leveza infantil inexiste nos gestos da mãe, a manutenção do lugar de margem é o que a mobiliza. A garota é a própria representação da dor, a dor da culpa e da vergonha, a dor da infância roubada pela prostituição: "a menina desfez as loiras tranças em cachos muito oxigenados passou 
batom muito vermelho se perfumou com o perfume da mãe e ficou de pé sem perguntar o que estava fazendo ali [...] - como é seu nome boneca?" (Cunha, 1990b, p. 15). Para a menina que deixa a casa dos tios, o consolo é não se ver obrigada a se destituir de externar sua aflição e incômodo para não desagradar a alguém.

As fibras do abuso e da opressão são imperceptíveis aos olhos dos adultos presentes nas tramas e continuam fiadas e torcidas no fio de violação física, psíquica e emocional, unindo uma a uma todas as garotas, todas presas aos nós dos diferentes abusos perpetrados contra sua infância. Dolores, esse poderia acompanhar o nome da personagem Lili ou ser o nome de qualquer uma das meninas inominadas aqui expostas. Todas vivenciaram a dor e a agonia de existir num mundo onde a infância não tem prerrogativas ou privilégios ante a crueldade social ou os equívocos emocionais.

Se a infância, muitas vezes, é retratada como o momento das mais plenas alegrias humanas, a narrativa de Helena Parente Cunha contraria essa lógica, apontando a carga de opressão, dor, sofrimento, vergonha e culpa que assola a vida de muitas meninas. Crianças que são, com a mobilidade muitas vezes controlada, é dentro dos lares, na escola ou nas suas proximidades, que as mais distintas situações oferecem-se na cartilha da vida como contato e aprendizagem dos desafios de existir.

\section{Referências}

ARIÈS, Philippe (1981). História social da criança e da família. Tradução de Dora Flaksman. 2. ed. Rio de Janeiro: LTC.

CHAUI, Marilena (s.d.). Repressão sexual: essa nossa (des)conhecida. São Paulo: Círculo do Livro.

CUNHA, Helena Parente (1990a). Cem mentiras de verdade. 2. ed. Rio de Janeiro: José Olympio.

CUNHA, Helena Parente (1990b). Os provisórios. 2. ed. Rio de Janeiro: Antares.

CUNHA, Helena Parente (2011). Falas e falares. Florianópolis: Mulheres.

FERREIRA, Aurélio Buarque de Holanda; FERREIRA, Marina Baird; ANJOS, Margarida dos (Coords.) (2010). Dicionário Aurélio da língua portuguesa. 5. ed. Rio de Janeiro: Positivo. 
FRAGA, Myriam (2008). Poesia reunida. Salvador: Assembleia Legislativa do Estado da Bahia.

LISPECTOR, Clarice (1994). Caridades odiosas. In: LISPECTOR, Clarice. A descoberta do mundo: crônicas. 4. ed. Rio de Janeiro: Francisco Alves.

POSTMAN, Neil (1999). O desaparecimento da infância. Tradução de Suzana Menescal de Alencar Carvalho e José Laurenio de Melo. Rio de Janeiro: Graphia.

ROCHA-COUTINHO, Maria Lúcia (1994). Tecendo por trás dos panos: a mulher brasileira nas relações familiares. Rio de Janeiro: Rocco.

RUA, Maria Adelaide (2007). Infância em territórios de pobreza: os falares e sentires das crianças. In: VASCONCELLOS, Vera Maria Ramos de; SARMENTO, Manuel Jacinto (Orgs.). Infância (in)visível. Araraquara: Junqueira e Marin.

SARMENTO, Manuel Jacinto (2007). Visibilidade social e estudo da infância. In: VASCONCELLOS, Vera Maria Ramos de; SARMENTO, Manuel Jacinto (Orgs.). Infância (in)visível. Araraquara: Junqueira\&Marin.

Recebido em setembro de 2014.

Aprovado em março de 2015.

\section{resumo/abstract}

\section{Abuso e repressão: fibras do mesmo fio na infância das meninas de Helena Parente Cunha}

\section{Lílian Almeida de Oliveira Lima}

A produção narrativa da escritora brasileira Helena Parente Cunha é marcada pela presença de personagens femininas e pela problematização desse universo, abalando estruturas e padrões hegemônicos. Avultam em suas tramas personagens jovens e maduras; todavia, as meninas também tomam lugar na denúncia de dores e opressões impostas por moldes culturalmente estabelecidos. Neste artigo, são destacados contos dos livros Os provisórios, Cem mentiras de verdade e Falas e falares, analisando-se as situações de abuso e repressão a que as crianças são submetidas, vislumbrando também as demarcações de gênero aí presentes. Essas personagens encontram-se submetidas a uma série de descuidos que abalam a noção idealizada de infância como o paraíso perdido. No percurso de análise vêm à baila as ideias de Neil Postman acerca do estreitamento dos limites que diferenciam adultos e crianças, bem como a noção de "privatização da infância" apontada por Jacinto Sarmento.

Palavras-chave: infância, gênero, conto, Helena Parente Cunha. 


\section{Abuse and repression: fibers of the same yarn in the childhood of Helena Parente Cunha's girls}

\section{Lílian Almeida de Oliveira Lima}

The narrative production of Brazilian writer Helena Parente Cunha is marked by the presence of female characters and the questioning of this universe, shaking structures and hegemonic standards. Young and adult women are the main characters of her plots, but the girls also take part in the complaint about the pain and the oppression imposed by culturally-established patterns. In this article, short stories of the books Os provisórios, Cem mentiras de verdade and Falas e falares are discussed, analyzing the situations of abuse and repression to which children are subjected, and the demarcations of gender present there. These characters are subjected to a series of oversights that undermines the idealized notion of childhood as a lost paradise. In the course of analysis the ideas of Neil Postman about narrowing the limits that differentiate adults and children are used, as well as the notion of 'privatization of childhood', pointed out by Jacinto Sarmento.

Keywords: childhood, gender, short story, Helena Parente Cunha. 